\title{
Supply Chain Management on Overseas Trade Enterprises
}

\author{
Ying CHEN \\ Xi'an University of Technology, Xian, China, P.C. 710048
}

\begin{abstract}
Supply chain management (SCM) has turned out to be latently precious approach to gaining access to competitive advantage and improving performance with increasingly escalating competition switching into among supply chains rather than between individual firms. This study is aimed at addressing influencing factors upon SCM of foreign trade firms and magnitudes. This study portrays the status concerning current literature in this area and summarizes five categories where each consists of several specific elements. Resorting to factor analysis, the study finds that establishing and integrating of SC cooperative relationship, SC flexibility, instituting and putting to use of information system are significant determinants whilst optimization of business procedure for SC and senior executives' belief, attitudes and backing. Amid these concrete determinants, ratio of business volume between a firm and its partners to its total turnover, joint decision-making in dealing patterns, fixing prices and drafting quality standards, member firms' mutual both trust and profit, and cushion capability defending environmental change are particularly significant for SCM success. Hence, it is necessary and imperative for foreign trade corporations to put efforts into these areas to consolidate according capability, eventually to achieve the aim of promoting SCM triumph.
\end{abstract}

Keywords-supply chain management, foreign trade firm, factor analysis, influencing factor, overseas trade company

\section{INTRDUCTION}

Supply Chain Management has been defined as the systemic, strategic coordination of the traditional business functions and tactics across these businesses functions within a particular organization and across businesses within the supply chain for the purposes of improving the long-term performance of the individual organizations and the supply chain as a whole (CLM 2000).SCM explicitly recognize the strategic nature of coordination between trading partners and to explain the dual purpose of SCM: to improve the performance of an individual organization, and to improve the performance of the whole supply chain. The goal of SCM is to integrate both information and material flows seamlessly across the supply chain as an effective competitive weapon (childhouse \& towill 2003).

China's economic reforms, begun in the late 1970s and progressing through its entry into the WTO in 2001, have allowed it to participate more fully in international commerce and to benefit from economic growth. The Chinese rapid economic growth has been outpaced only by its even more rapid increases in international trade participation as well as receipt of foreign direct investment (FDI). For three decades, the nation has registered a flying expansion in international trade, with an annual average rise of $15.01 \%$ and $13.96 \%$ for exports and imports, ranking the first place not only in the case of both tangible exports since 2009 but in aggregate imported \&exported commodities as of 2013 and making a breakthrough above the trade value of $\$ 4$ trillion for the same year. However, the nation has suffered a host of painful problems in overseas trading activity like "high energy consumption, high input, and low efficiency" and high frequent anti-dumping and 755 countervailing investigations by trading countries. Additionally, global and home markets are tending to a fiercer competition and a flurry of lashes is surging out of the US's financial plague and the sovereignty debit crisis in Europe. As a result, the development for China's overseas trade is confronting a number of troubles and hidden dangers. Under this climate, it is necessary and imperative for Chinese trading corporations to adapt themselves to the changing environment through formulating and implementing flexible strategies. For this, SCM can provide valuable tips and inspirations for them making a survival and profit on the global market where competition has evolved into between supply chains from inter-firms.

The aim of this paper is dedicated to the growing body of literature on supply chain management by answering key research questions based on questionnaires and factor analysis. It has made two main contributions. First, the paper, on the ground of the findings from current literature, explores and deduces the process and success factors for modern SCM. The other contribution is to probe into SCM's value-added areas by virtue of surveying exporting supply chains' operating means by both traditional trading firms and forward-thinking. This will advance Chinese trading companies to improve competitiveness in the ever-increasingly strong competition market and ultimately the nation's exporting commerce to sustainably development.

The main findings are that of the five factors of sparking SCM success, the building and integrating of SC collaboration relationship is the most important, SC suppleness ranks No. 2 and constructing and taking advantage of information system play the third vital role. In connection with maximizing the SC business procedure and senior management's belief, attitude and support, they exercise a comparatively tiny effect.

The remainder of this paper is organized as follows. Section 2 contains an overview of literature review and research framework, developing the hypothesized relationships. Empirical analysis is presented section 3. We conclude in section 4.

\section{LITERATURE, CONCEPTUAL MODEL AND HYPOTHESIS}

\section{A. Overview of current literature}

Supply chain management has triggered interest of academia recent years and received investigations based on multi-levels and multi-perspectives. Mental et al.(2001) defined supply chain management as the system \& strategy coordination of the traditional business function, with its tactics being crossing a certain firm's commercial function and units in the chain for the sake of improving each individual company's and the whole chain's forward performance (mentzer et al. 2001) . D. J. Flint (2004) argued that supply chain management has emerged as a critical arena in which 
firms can find significant cost reduction opportunities, giving them a cost advantage over competitors (flint 2004). The finding from John et al (2007) is that strategic supply chain management (SSCM) is the strategic, operational, and technological integration of supply chain organizations and activities through relationships, processes, and information sharing to provide member organizations a competitive advantage.

\section{B. Establishment and coordination concerning SCM co-operational relationship}

SCM co-operational relation is understood to be an agreement relation in which members in the chain co-share information, risks and profits. Through the evidence of Ireland's electrical industry Fynes et al.(2005) found that SCM cooperation relationship is relevant to the chain's performance in line with consequences stemming from the Chinese investigators(lin et al. 2008, liao et al. 2008).

In view of this, this study maintains that the entering into and integration of SCM relationship is one of factors that contribute to success in supply chain management of import-export corporations. This, coupled with the import \& export companies' own distinguishing features, further leads to a condensing of five specific elements embracing choice of partners, proportion of the transaction volume between a party and other parties in the aggregate of the party, mutual belief degree, joint decision-making over dealing mode, price and quality standard, and level in inter-partners' communications and harmonization. So, we propose the hypothesis

Hypothesis 1. The establishing and integration of supply chain collaboration relationship has a positive effect upon SCM victory for foreign trade businesses.

\section{Flexibility}

It is Slack (1987) who first proposes the concept of supply chain flexibility, which denotes ability for the chain to respond to customer demand. Since then, a host of scholars have treated flexibility as an important indicator assessing performance of SCM. In the context of globally economic volatility and uncertainty, flexible capability has evolved into a powerful instrument whereby to combat environmental uncertainties and then develop a sustainable competitive advantage for foreign trade firms. So, this study holds that supply chain flexibility is one of factors giving rise to successful management of overseas trade businesses, which is embodied in three dimensions-buffer capacity of, adaptive faculty to and innovation ability to defend environmental change. The following assumption is made.

Hypothesis H2. SC flexibility exerts an active clout on foreign trade enterprises' SCM success.

\section{Establishment and use of information system.}

Information sharing is acknowledged a critical ingredient for any SCM system(Moberg et al. 2002) . Current literature have displayed that the key to the seamless supply chain is making available undistorted and up-to-date marketing data at each node within the chain (childhouse \& towill 2003). Via taking the data available and sharing it with other parties in the chain, each member is in a position to expedite the information flow, improve the efficiency and effectiveness, and make a swift response to ever-variable customer and wants and needs. As a result, sharing of information can eventually contribute to a competitive and comparative advantage for per organization in the supply chain. Furthermore, it matters a great deal for the significance of information sharing upon a chain's performance 756 what information is enjoyed together, when and how it is shared, and with whom. It seems that there is an intrinsic unwillingness inside organizations to give away more than minimal information since information disclosure is perceived as a loss of power and firms suffer a terror that information may seep out to latent competitors (Berry 1994, li \& Lin 2006).

The establishment and adopting of information system for supply chain management has evolved into the most fundamental and critical means to achieve the expected object and performance. As far as import \& export corporations are concerned, information technology has been far and wide used in commercial activity and become an infrastructure for an individual business. Thus, we argue that "setting up and utilizing an information system" is one of determinants to be dedicated to successful SCM, comprising two components-the system's degree of perfection and staff competence in operating and applying the system. And this triggers a supposition.

Hypothesis H3. The establishment and application regarding information system is an affirmative driver of SCM triumph.

\section{E. Optimization of business procedure}

Optimizing the business procedure for supply chain represents redesigning the whole chain's business process with a view to adapting to change in the competitive climate and end-users and seeking to achieve a considerable improvement concerning each performance in SCM. Obviously, business procedure optimization is both an effective means and a powerful guarantee for winning SCM. Hence, the study views optimization of business procedure as one of factors to contribute to succeeding in SCM of foreign trade enterprises and decomposes it into four components- working procedure of whole operation, distinguishing one's own core business and outsourcing non-core business, possessing an organizational architecture productive to optimizing of business course and being equipped with ability to optimize the flows of work, materials, information and funds. Likewise, it is reasonable to make a hypothesis.

Hypothesis H4. SC business procedure optimizing influences positively on victorious SCM.

\section{F. Idea, attitude and support of Senior Management}

In light of Lee and Kim (1999), SCM support deriving from high-level executives is the degree to which they place emphasis on, comprehend and back specific interests to be incurred by cooperation with partners.

It is of utmost importance whether putting into practice the adoption and implementation of SCM strategies is reliant on senior management's endorsement. Consequently, in this study the idea, attitude and backing emanating from top mangers is considered one factor that contributes to succeeding in running SCM, which can be divided into six elements-, namely, six undertakings calling for to being completed by higher-level employees-instituting the customer-centered, market-oriented thought, being aware of the importance of SCM to the company, appreciating SCM-related knowledge by high-level employees, getting involved in decision-making on SCM, granting full authorization to SCM and providing sufficient support for SCM. Likewise, we put forward the final hypothesis for this study.

Hypothesis H5. Senior management's beliefs, attitudes and support spark off a right impact on SCM. 


\section{EMPIRICAL INVESTIGATION}

The train of thought in the paper is that it first defines issues to be researched by virtue of qualitative analysis and then resorts to a quantitative technique to test the proposed hypotheses on the basis of data available through interviews and questionnaires. And ultimately finds out a genuine relationship between SCM and trading companies from domestic and abroad. Note that tables 1, 2, 3 and 4 display reliability tests, factors and indicators for SCM, variance-explaining validity, and rotated components and component scores.

\section{A. Questionnaire designing and data collection}

Employees in international trade corporations, purchasing clerks, suppliers, producers, clients of overseas shopping, purchasers, forwarders, consultants and strategic professionals fall into the category of respondents in connection with questionnaires. These questionnaires are mailed to all possible testees, and if there is no response from one person within a given period, another questionnaire will be posted again. There is a total of 500 E-mail addresses to be obtained via releasing questionnaires, amid which 23 addresses go wrong, so that, 477 copies are successfully delivered, and eventually 186 copies come back with 3 being declined for not having answered all questions raised in the questionnaire, thereby there being a response rate of 38 ( 183/477). In the final samples, there are 16 corporate principals, 122 supervisors, 36 purchasing managers and 9 additional post persons, most of them are taken on in medium \&large sized institutions with half exceeding RMB 0.1 billion in annual turnover and $30 \%$ more than employees.

\section{B. B. Reliability and validity}

Initially, we conduct a test of the questionnaire's reliability through the Cronbach's coefficient $\alpha$, which is considered rather good given above 0.80 and respectively acceptable both if within the internal $[0.70,0.80]$ and inside the internal $[0.60,0.70]$ plus the five-point Likert scale surpassing 0.70 . Table 1 displays the results in connection with confidence analysis, finding out that our questionnaire enjoys a high confidence and is of rationality.

Next, we apply KMO and Bartlett techniques into validity investigation. The more close to $1, \mathrm{KMO}$, an indicator of comparing coefficients of correlation and partial coefficients, demonstrates the more effective there will a result to stem from factor analysis of these variables. By virtue of calculation, $\mathrm{KMO}$ is assessed at 0.80 , suggesting the outcome generated by the factor analysis is of acceptability.

\section{C. Factor analysis}

The study employs principal components to make a processing of sampling data and choose the factors whose accumulation value outstripping $70 \%$ and eigenvalue in excess of 1 (calculations on table 3 ). Table 3 showcases that 5 factors are selected for their accumulative variance of $75 \%$. Furthermore, on the basis of matrix of loadings and weight, specific indicators for various categories of factors are fixed for empirical analysis purposes.

The weight for per factor multiplying the score thereof can contribute to the relationship equation in connection with winning SCM and corresponding determinants and the magnitude of each determinant:

$$
X=24.04 \% C_{1}+19.13 \% C_{2}+15.23 \% C_{3}+10.12 \% C_{4}+7.43 \% C_{5}
$$

In which $\mathrm{C} 1, \mathrm{C} 2, \mathrm{C} 3, \mathrm{C} 4$ and $\mathrm{C} 5$ denote the first, second, third, fourth and fifth main component, respectively.

In the first common factor, each sub-factor has a heavy loading and gets a high score, especially F12 and F14, displaying that in $\mathrm{SC}$ management activity a significant role is played by $\mathrm{C} 1$ where $\mathrm{F} 12$ and F14 are particularly strong. Under the category of the second main factor F2, F21 and F23 are significant with the equal 0.85 loading and a 0.19 score and 0.18 score, separately. For the third main factor F3, F31 exerts the same effect as and F32 for having the same load and score, 0.85 and 0.58 , while F44, topping at the 0.92 loading and 0.31 score, is the most crucial contributor of F4. With regard to F5, there are three sub-factors whose functions are momentous, all valued at 0.97 in loading and 0.28 in score.

It can be implied that entering into and coordinating of SC collaboration relationship, flexible capacity and building and application of information system are main factors that contribute to SCM hit while optimization in SC business procedure and executives' belief, attitude and plunking for play a comparatively minor part. Consistent with the current reality concerning China's foreign trade corporations, the core thought on SCM places the great emphasis upon cooperation and integration, an objective that is achieved mainly through a sophisticated information system. Hong Kong Lifeng Company has evolved into a role model amid the global trading businesses in SC operations by virtue of resorting to superior information system and efficient mechanism of SC team-working and harmonizing. Additionally, companies of international trade have been submerging into global volatility of macro-economy, many plunging into bankruptcy since the financial turmoil a few years ago and only those surviving the crisis and developing stronger that are equipped with formidable suppleness. So, flexibility is acknowledged one of critical determinants that give rise to succeeding in SCM for import\& export firms.

A new era has approached to this world, when SCM awareness and belief are extending to the industrial circle where many executives and employees in commercial companies receive training opportunities and grasp knowledge relevant to SCM, even quite a number of them specialize in MBA degree and acquire abundant management techniques. As a result, they, during the course of fulfilling SCM practices, are sufficient in momentum to take action and are adequate in competence to achieve the expected goal. So, this factor has not been a key one any longer to curb the success of SCM for trading businesses.

In the context of furthering reform in China's economic and foreign trade system, trade enterprises have gradually accomplished the transformation of their operating patterns from separating manufacturing from exportation into supply chain integration. This, coupled with less difficulty in the chain's business procedure optimization because of comparative simplicity in supply chain composition of overseas trade firms beside manufacturing counterparts, and, a great deal of victorious experience of optimization accumulated by companies, contributes to "optimizing of SCM business process has become an ordinary job', meaning that it is a necessary but trivial element influencing on SCM success.

\section{CONCLUSIONS AND IMPLICATIONS}

The study is motivated to have an understanding of factors regarding SCM and their magnitudes of foreign trade companies. The study falls back on the methodology of factor 757 analysis, gleaning a broad range of new insights into SCM. 
Amid five factors of sparking SCM success, the setting up and integrating of SC collaboration connection is the most significant, SC suppleness ranks No. 2 and constructing and taking advantage of information system play the third vital role. With reference to maximizing the SC business procedure and senior management's belief, attitude and support, they exercise a comparatively tiny effect.

With economic globalization emerging, conventional trading firms are faced with challenges and difficulties with their past advantages having faded. Environmental uncertainty including ambiguity in suppliers, market demand and science-technology, disorganize traditional corporations' arrangement, which is lack of competitive advantages like market elasticity, adaptation, responsiveness and innovativeness due to being roughly drafted on the basis of past experience. Medium \& small-sized exporting corporations, which, driven by national export subsidies, bulkiness of overseas markets and a low threshold to exporting business, once were springing up, suffer a weak awareness of network inter-linkage with SC companies, a poor capability of integration and a low coordination effect and fragility in the market. These firms seem not to attach importance to the supplying strategy. Typically, in planning and controlling that is crucial to company operation, they concern with immediate business development and ignore of a long planning. Additionally, these kinds of firms are interested in pursuit of diversity of business development in conformity with market trends while fall into shortage of a thorough planning and controlling. Consequently, in the long run, companies are easy to misplace their development orientation and deprive their market-leading role, and ultimately descend to insolvency.

\section{ACKNOWLEDGEMENTS}

The author wishes to place on record her deep gratitude to Shaanxi Education Department for its financial assistant under the program No.107-00K1208 titled on the effects of FDI technological spillovers upon Shaanxi's industrial composition.

TABLE I. RELIABILITY

\begin{tabular}{|c|c|c|c|c|c|}
\hline Survey & Cronbach's $\alpha$ & No. of Questions & Name & Cronbach's $\alpha$ & No. of Questions \\
\hline$F_{1}$ & 0.79 & 5 & $F_{4}$ & 0.88 & 4 \\
\hline$F_{2}$ & 0.74 & 3 & $F_{5}$ & 0.90 & 6 \\
\hline$F_{3}$ & 0.64 & 2 & E & 0.81 & 20 \\
\hline
\end{tabular}

Note: Form E denotes the sum of factors contributing to SCM success.

TABLE II. FACTORS AND INDICATORS

\begin{tabular}{|c|c|c|}
\hline & Factor & Sub-factor (sign/implication) \\
\hline $\mathrm{F}_{1}$ & $\begin{array}{l}\text { Establishment and Integration of SC } \\
\text { cooperation }\end{array}$ & $\begin{array}{l}F_{11} \text { Reasonable Choice of cooperative businesses } \\
F_{12} \text { Ratio of turnover with partners in all business volume } \\
F_{13} \text { Degree of mutual belief and mutual benefit } \\
F_{14} \text { Joint decision-making in fixing the transactional mode, price and quality } \\
\text { standard } \\
F_{15} \text { Competence of communication and coordination with partners }\end{array}$ \\
\hline $\mathrm{F}_{2}$ & SC flexibility & $\begin{array}{l}F_{21} \text { Cushioning ability to combat environmental change } \\
F_{22} \text { Adaptability to environmental change } \\
F_{23} \text { Innovative ability to cope with environmental change }\end{array}$ \\
\hline $\mathrm{F}_{3}$ & Building and use of information system & $\begin{array}{l}F_{31} \text { Degree of information system perfection for propping up SCM } \\
F_{32} \text { Staff's capability of performing SCM assignments by use of information } \\
\text { system }\end{array}$ \\
\hline $\mathrm{F}_{5}$ & $\begin{array}{l}\text { Belief, attitude and support of senior } \\
\text { management }\end{array}$ & $\begin{array}{l}\mathrm{F}_{51} \text { Senior management can radicate the customer-oriented concept } \\
\mathrm{F}_{52} \text { Senior management are familiar with the importance of SCM } \\
\mathrm{F}_{53} \text { Senior management understand SCM-related knowledge } \\
\mathrm{F}_{54} \text { Senior management are actively involved in SCM decision-making } \\
\mathrm{F}_{55} \text { Senior management provide full authorization for SCM } \\
\mathrm{F}_{56} \text { Senior management offer powerful aid to SCM }\end{array}$ \\
\hline
\end{tabular}




\begin{tabular}{|l|c|c|c|c|c|c|}
\hline \multirow{2}{*}{} & \multicolumn{3}{|c|}{ Extractions sums of squared loadings } & \multicolumn{3}{c|}{ Rotations sums of squared loadings } \\
\cline { 2 - 8 } & total & variance $\%$ & cumulative $\%$ & total & percentage of variance & cumulative $\%$ \\
\hline $\mathrm{C}_{1}$ & 4.91 & 24.55 & 24.55 & 4.61 & 23.04 & 23.04 \\
\hline $\mathrm{C}_{2}$ & 4.48 & 22.39 & 47 & 3.83 & 19.13 & 42.17 \\
\hline $\mathrm{C}_{3}$ & 2.60 & 13.02 & 60 & 3.05 & 15.23 & 57.40 \\
\hline $\mathrm{C}_{4}$ & 1.60 & 8.01 & 68 & 2.02 & 10.12 & 67.52 \\
\hline $\mathrm{C}_{5}$ & 1.40 & 7.00 & 75.0 & 1.49 & 7.43 & 74.95 \\
\hline
\end{tabular}

TABLE IV MATRIX FOR ROTATED COMPONENT AND COMPONENT SCORE COEFFICIENT

\begin{tabular}{|c|c|c|c|c|c|c|c|c|c|c|}
\hline & Rotated & component & matrix & & & Component & score & coefficient & & \\
\hline & $\mathrm{C}_{1}$ & $\mathrm{C}_{2}$ & $\mathrm{C}_{3}$ & $\mathrm{C}_{4}$ & $\mathrm{C}_{5}$ & $\mathrm{C}_{1}$ & $\mathrm{C}_{2}$ & $\mathrm{C}_{3}$ & $\mathrm{C}_{4}$ & $\mathrm{C}_{5}$ \\
\hline $\mathrm{F}_{11}$ & 0.50 & 0.20 & -0.006 & -0.036 & 0.093 & 0.10 & 0.08 & -0.007 & -0.031 & 0.012 \\
\hline $\mathrm{F}_{12}$ & 0.85 & -0.09 & 0.057 & 0.081 & -0.103 & 0.19 & -0.083 & 0.05 & 0.033 & -0.018 \\
\hline $\mathrm{F}_{13}$ & 0.69 & 0.13 & -0.014 & -0.202 & 0.22 & 0.15 & 0.02 & -0.02 & -0.096 & 0.074 \\
\hline $\mathrm{F}_{14}$ & 0.85 & 0.026 & -0.015 & 0.166 & -0.13 & 0.18 & -0.016 & 0.007 & 0.06 & -0.04 \\
\hline $\mathrm{F}_{15}$ & 0.69 & 0.043 & -0.098 & -0.037 & -0.002 & 0.15 & -0.009 & -0.064 & -0.02 & 0.012 \\
\hline $\mathrm{F}_{21}$ & -0.09 & 0.85 & 0.057 & 0.081 & -0.103 & -0.08 & 0.19 & 0.05 & 0.033 & -0.018 \\
\hline $\mathrm{F}_{22}$ & 0.13 & 0.69 & -0.014 & -0.20 & 0.22 & 0.02 & 0.15 & -0.02 & -0.096 & 0.074 \\
\hline $\mathrm{F}_{23}$ & 0.026 & 0.85 & -0.015 & 0.17 & -0.13 & -0.02 & 0.18 & 0.007 & 0.06 & -0.043 \\
\hline $\mathrm{F}_{31}$ & -0.024 & 0.05 & 0.85 & -0.104 & -0.08 & -0.001 & 0.03 & 0.58 & -0.024 & -0.033 \\
\hline $\mathrm{F}_{32}$ & -0.014 & -0.03 & 0.85 & 0.064 & 0.08 & 0.003 & -0.02 & 0.58 & 0.04 & -0.034 \\
\hline $\mathrm{F}_{41}$ & -0.06 & 0.14 & -0.008 & 0.80 & 0.025 & -0.026 & 0.05 & 0.012 & 0.27 & -0.063 \\
\hline $\mathrm{F}_{42}$ & 0.02 & 0.12 & 0.003 & 0.80 & 0.17 & -0.007 & 0.016 & 0.01 & 0.27 & -0.02 \\
\hline $\mathrm{F}_{43}$ & 0.07 & -0.037 & 0.006 & 0.81 & 0.12 & 0.011 & -0.07 & 0.015 & 0.28 & -0.011 \\
\hline $\mathrm{F}_{44}$ & 0.02 & 0.008 & -0.05 & 0.92 & 0.17 & -0.002 & -0.055 & -0.023 & 0.31 & -0.004 \\
\hline $\mathrm{F}_{51}$ & 0.115 & 0.20 & 0.013 & 0.116 & 0.95 & -0.02 & -0.07 & 0.009 & -0.01 & 0.5 \\
\hline $\mathrm{F}_{52}$ & 0.115 & 0.20 & 0.013 & 0.116 & 0.95 & -0.02 & -0.07 & 0.009 & -0.01 & 0.5 \\
\hline $\mathrm{F}_{53}$ & -0.02 & 0.22 & 0.03 & 0.177 & 0.82 & -0.005 & 0.008 & -0.03 & 0.001 & 0.22 \\
\hline $\mathrm{F}_{54}$ & 0.002 & 0.09 & 0.07 & 0.12 & 0.97 & 0.008 & -0.082 & -0.016 & -0.023 & 0.28 \\
\hline $\mathrm{F}_{55}$ & 0.002 & 0.09 & 0.07 & 0.12 & 0.97 & 0.008 & -0.082 & -0.016 & -0.023 & 0.28 \\
\hline $\mathrm{F}_{56}$ & 0.002 & 0.09 & 0.07 & 0.12 & 0.97 & 0.008 & -0.082 & -0.016 & -0.023 & 0.28 \\
\hline & & & & & & & & & & \\
\hline
\end{tabular}

\section{REFERENCES}

[1] Berry D., Towill D.R. and Walsley N. Supply chain management in the electronics products industry. International Journal of Physical Distribution and Logistics Management ,1994, 24(10):20-32.

[2] Council of logistics Management. What it's about. Oak Brook: CLM, 2000.

[3] Childhouse P. and Towill D.R. Simplified material flow holds the key to supply chain integration. OMEGA, 2003, 31(1):17-17.

[4]Flint D. J. Strategic marketing in global supply chains: Four challenges. Industrial Marketing Management, 2004, 33:45-50.

[5]Fynes B, Voss C and Burca S. The impact of supply chain relationship quality on quality performance. International Journal of Production Economics ,2005, 96: 339-354.

[6] Lee $\mathrm{J}$ and Kim Y. Effect of partnership quality on is outsourcing: Conceptual framework and empirical validation. Journal of Management Information Systems, 1999, 15(4):26-61.

[7] Liao L., M.Q. Ming and Y. Long. An empirical study on the relationship among collaborative relationship, agile supply chain and business performance. Systems, Engineering-Technology \& Practice 2008, 06:115-125.

[8] Lin J., Xue Y, Cao H.L. and Li S.Ch. A theoretic study of the effects of buyer-supplier relationships on cooperative performance of buyer. Soft Science, 2008, 22 (04):1-7.

[9] Li S. and Lin B. Accessing information sharing and information quality in supply chain management. Decision Support Systems, 2006, 42:1641-1656.

[10] Mentzer J T, DeWitt W, Keebler J S, et al. Defining supply chain management. Journal of Business Logistics, 2001, 22.(2): 1-25.

[11] Moberg C.R., Cutler B.D., Gross A. and Speh T.W. Identifying antecedents of information exchange within supply chains. International Journal of Physical Distribution and Logistics Management , 2002, 32(9):755-770.

[12] Slack N. The flexibility of manufacturing systems. International Journal of Operations and Production Management ,1987, 7(4): 35-45.

[13]Upson J. W, David J.R. and Ketchen R. Managing employee stress: a key to the effectiveness of strategic supply chain management. Organizational Dynamics, 2007, 36 (1): 78-92. 